\title{
Daya Dukung Perairan Rawa Mesangat Sebagai Habitat Buaya Siam
}

\author{
Teguh Muslim¹, Dwi Wahyu Mentari,1,2, dan Nanda Farhazakia1,2
}

${ }^{1}$ Balai Penelitian dan Pengembangan Teknologi Konservasi Sumber Daya Alam; e-mail: thegue97@gmail.com ${ }^{2}$ Herbarium Wanariset Samboja Balitek KSDA

\begin{abstract}
ABSTRAK
Rawa Mesangat merupakan habitat utama buaya Siam yang tersisa di Indonesia dan juga sebagai lokasi utama bagi nelayan sekitar. Produksi ikan sebagai sumber ekonomi masyarakat sekaligus makanan potensial bagi buaya Siam dapat terus berkelanjutan bila rantai makanan ekosistem tidak terputus dengan syarat kualitas perairan yang sehat. Pengambilan sampel air $\pm 1200 \mathrm{ml}$ di setiap lokasi yang dilakukan di 6 (enam) lokasi dalam area perairan rawa Mesangat. Analisis kualitas air dilakukan di laboratorium Peraikanan dan Ilmu Kelautan. Kualitas perairan menunjukkan pH yang normal, BOD 0,12 - 1,25 ppm termasuk dalam kategori tercemar rendah, COD 15,54 - 40,58 ppm dalam kategori tidak layak untuk kehidupan biota perairan, CO2 2,80 - 5,19 ppm kategori baik, TDS rendah antara 65 - $131 \mathrm{mg} / \mathrm{L}$, TSS berkisar 7 - $87 \mathrm{mg} / \mathrm{L}$, DO antara 2,86 $3,19 \mathrm{mg} / \mathrm{L}$, kadar nitrat tertinggi adalah $0,21 \mathrm{mg} / \mathrm{L}$ sedangkan kadar nitrat terendah 0,01 mg/L, kisaran suhu air antara 26 32oC, nilai Zn (seng) berkisar antara $<0,003-0,02 \mathrm{mg} / \mathrm{l}$. Perbedaan kualitas air pada setiap lokasi dapat disebabkan oleh faktor tutupan vegetasi pohon, vegetasi terapung, kekuatan arus sungai atau sirkulasi aliran air. Vegetasi terapung yang menyebar luas di perairan rawa sangat mungkin mempengaruhi kualitas air, salah satu contohnya adalah Salvinia molesta yang dapat memulihkan kualitas air atau sebaliknya tergantung kuantitas penutupan pada permukaan perairan.
\end{abstract}

Kata kunci: Ekosistem, Buaya Siam, Ikan, Sumber makanan, Vegetasi terapung.

\begin{abstract}
The Mesangat Swamp is the main habitat of the remaining crocodiles in Indonesia as well as a prime location for nearby fishermen. Fish production as an economic source of society as well as potential food for the Siamese crocodile can continue to be sustainable when the food chain ecosystem is not disconnected with the condition of healthy water quality. Water sampling of $\pm 1200 \mathrm{ml}$ in each location carried out at 6 (six) locations within the Mesangat Swamp water area. The analysis of water quality is done in the Fishery and marine Sciences laboratories. The quality of the water indicates a n ormal $\mathrm{pH}$, the BOD $0.12-1.25 \mathrm{ppm}$ belongs to the low tainted category, COD $15.54-40.58 \mathrm{ppm}$ in a category not feasible for the life of aquatic biota, CO2 2.80 - 5.19 ppm good category, low TDS between $65-131 \mathrm{mg} / \mathrm{L}$, TSS range 7 - $87 \mathrm{mg} / \mathrm{L}$, DO between $2.86-3.19$ $\mathrm{mg} / \mathrm{L}$, highest nitrate level is $0.21 \mathrm{mg} / \mathrm{L}$ while lowest nitrate rate is $0.01 \mathrm{mg} / \mathrm{l}$, water temperature range between $26-32 \mathrm{oC}$, The value of Zn (zinc) ranges between $<0.003-0.02 \mathrm{mg} / \mathrm{L}$. The difference in water quality at each location can be caused by the tree vegetation cover factor, floating vegetation, river current strength or water flow circulation. Floating vegetation that is widespread in swamp waters is very likely to affect water quality, one example is Salvinia molesta that can restore water quality or vice versa depending on quantity closure on water surface.
\end{abstract}

Keywords: Ecosystem, Siamese Crocodile, Fish, Food source, Floating vegetation

Citation: Muslim, T., Mentari,D.W., dan Farhazakia, N.(2020). Daya Dukung Perairan Rawa Mesangat Sebagai Habitat Buaya Siam. Jurnal Ilmu Lingkungan, 18(3), 436-445, doi:10.14710/jil.18.3.436-445

\section{Pendahuluan}

Walaupun laju perusakan hutan relatif cepat, ada beberapa lokasi habitat Buaya Siam masih dalam kondisi baik yang terdapat di luar kawasan lindungan yaitu Danau Mesangat (Kurniati, 2007a). Danau Mesangat sudah diusulkan oleh Wetland International-Indonesia Programme menjadi lokasi lahan basah yang diprioritaskan dalam konservasi (Wibowo, 1997). Danau Mesangat sebenarnya bukan merupakan tipikal sebuah danau, tetapi lebih mirip rawa air tawar yang luas (Kurniati, 2007b).

Buaya Siam (Crocodylus siamensis) sendiri merupakan bagian yang sangat penting sebagai spesies kunci bagi ekosistem Mesangat terlebih buaya ini sebagai salah satu jenis yang paling terancam di 436 dunia dan nyaris punah di habitat alaminya (Simpson et al., 2010).

Buaya Siam memangsa beberapa jenis makanan bergantung pada ukuran tubuhnnya (Copper et al., 1993). Behler et al. (2018), menyebutkan beberapa komponen jenis makanan buaya Siam diantaranya serangga, siput, ikan, burung, ular dan mamalia kecil. Serangga, siput dapat digolongkan sebagai hewan makrobentos yang lebih umum dimakan buaya anakan dan remaja (Shahrul and Stuebing, 1996).

Jenis satwa lain yang teridentifikasi dan mungkin berpotensi sebagai sumber makanan bagi buaya Siam relatif tersedia dengan kecukupan yang bervariasi dari kelompok serangga dan siput yaitu: Laba-Laba (Aracnida), Anggang-anggang (Hemiptera), Keong 
Muslim, T., Mentari,D.W., dan Farhazakia, N.(2020). Daya Dukung Perairan Rawa Mesangat Sebagai Habitat Buaya Siam. Jurnal IImu Lingkungan, 18(3), 436-445, doi:10.14710/jil.18.3.436-445

(Pila ampullaceal) dan Serangga air (insect). Beberapa jenis tersebut sangat mungkin berpotensi sebagai sumber makanan alami buaya Siam di rawa Mesangat. (Muslim dan Garsetiasih, 2019)

Sedangkan ikan merupakan sumber pakan utama dari usia anakan (juvenile) sampai dewasa (Datry et al., 2003). Ikan sering berada disekitar vegetasi terapung yang menjadi mangsa buaya anakan (Platt et al., 2006). Sedangkan berdasarkan hasil penelitian Behler et al. (2018) disebutkan bahwa 9 dari 11 buaya anakan dan remaja mengkonsumsi ikan. Keberadaan buaya Siam sendiri tidak membawa ancaman bagi nelayan dan sumber daya ikan.

Permukaan air yang sebagian besar ditutupi oleh vegetasi terapung. Proses sedimentasi berakselerasi dengan pertumbuhan gulma air (Kurniati, 2007b). Tumbuhan air termasuk gulma dan vegetasi terapung merupakan tumbuhan yang tinggal di sekitar air dan di dalam air yang berfungsi sebagai fitoremediasi pada suatu ekosistem (Priadie, 2012). Keberadaan tumbuhan air yang hidup dengan baik akan menciptakan produktivitas perairan yang tinggi dan menghasilkan keanekaragaman biota akuatik yang tinggi pula. Beberapa peranan tumbuhan air yang sangat penting adalah sebagai produsen primer, sebagai habitat biota, tempat perlindungan dan tempat menempel berbagai hewan dan tumbuhan atau alga (Boyd, 1990). Disamping itu, tumbuhan air dapat juga sebagai daerah asuhan, padang pengembalaan dan makan dari berbagai jenis ikan herbivora, hal ini terlihat dari banyaknya larva-larva

dan juvenil biota air yang ditemukan pada tumbuhan air. Daun tumbuhan air yang lebat dan besar pada jenis tertentu akan memperlambat air yang disebabkan oleh arus sehingga perairan di sekitarnya menjadi tenang. Disamping itu, rimpang dan akar dapat menahan dan mengikat sedimen, sehingga dapat menguatkan dan menstabilkan dasar permukaaan.

Artikel ini bertujuan untuk memberikan informasi daya dukung perairan sebagai habitat buaya Siam termasuk didalamnya adalah kualitas air, potensi sumber makanan alami, dan ancaman bagi kelestarian makhluk hidup di lahan basah rawa Mesangat terutama bagi populasi buaya Siam.

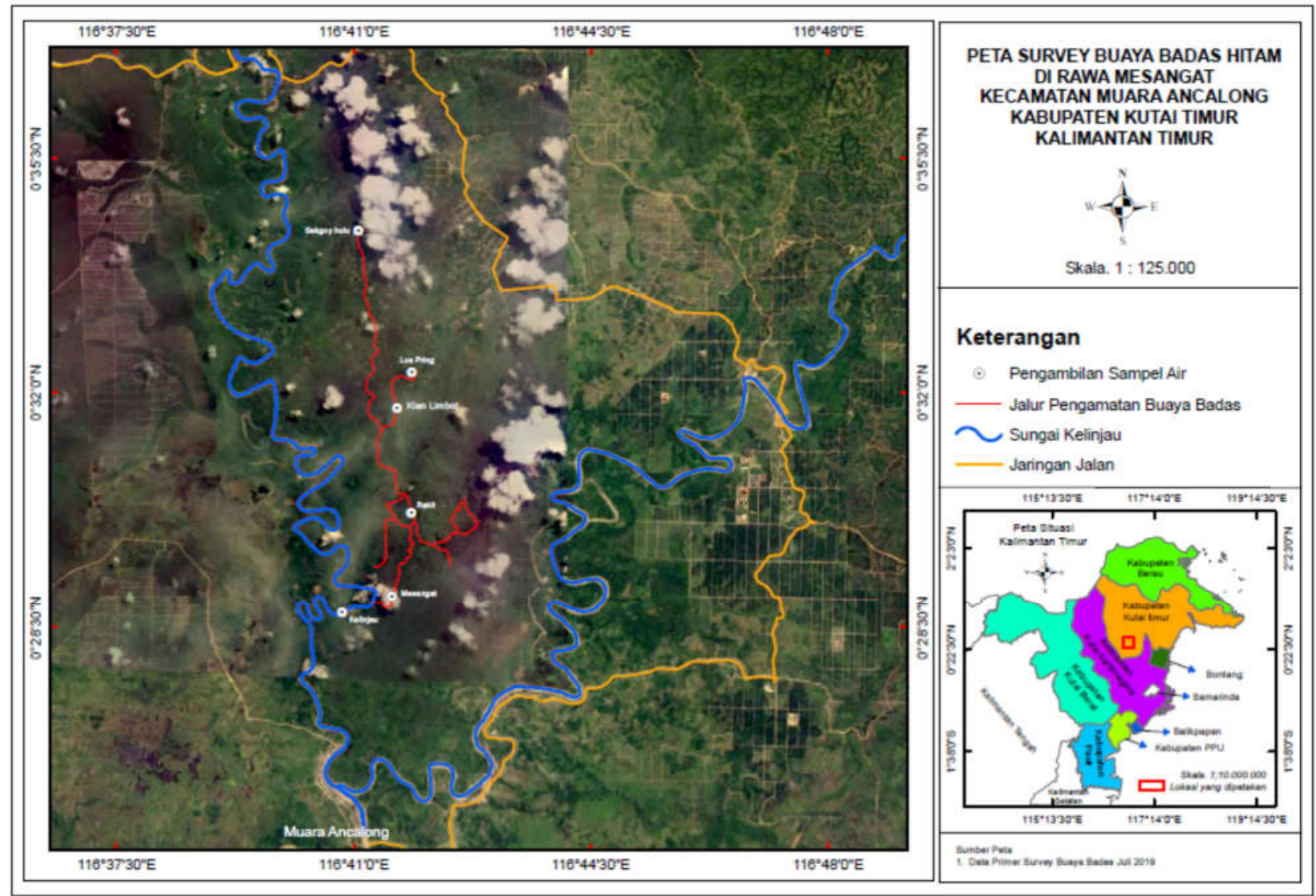

Gambar 1. Lokasi survei dan pengambilan sampel air di Lahan Basah Mesangat

\section{Bahan dan Metode}

Pengambilan sampel dilakukan dengan menggunakan metode purposif yaitu pada 6 titik yang telah ditentukan berdasarkan pada lokasi habitat buaya Siam di rawa Mesangat. (Gambar 1). Pengambilan sampel air pada saat level air di areal Rawa Mesangat relatif tinggi $(40-259 \mathrm{~cm})$. Level air bervariasi antara 30-380 cm tergantung musim (Behler et al. 2018) dan dapat mengakses beberapa lokasi pada bulan April - Mei 2018.

Sebanyak 6 titik lokasi pengambilan sampel air di rawa Mesangat (Gambar 1), antara lain: Mesangat Hilir, Sekgoy Hulu (4/27/2018) 17:53, 50N 466024 58138 97ft), Kelinjau, Rakit (4/24/2018) 16:26, 50N 
4664365545923 Ft), Luah Pring (4/27/2018) 17:11 50N 46649759434183 Ft), Klan Limbot. Sampel air dimasukan dalam botol air mineral sebanyak $1200 \mathrm{ml}$. Analisa sampel air dilakukan di Laboratorium Kualitas Air Fakultas Perikanan dan Ilmu Kelautan Universitas Mulawarman. Kriteria penilaian kualitas air berdasarkan Baku Mutu sesuai dengan Perda Provinsi KalTim No. 02 thn 2011 Lamp. V Kelas 2.

\section{Hasil dan Pembahasan \\ 3.1 Kualitas Perairan Rawa Mesangat}

Parameter pengujian kualitas air (Tabel 1) menunjukkan kualitas perairan rawa Mesangat relatif baik berdasarkan standar baku mutu yang ditetapkan dalam Perda Provinsi Kalimantan Timur No. 02 Tahun 2011.

Tingginya tingkat kekeruhan akan berpengaruh terhadap kehidupan biota secara langsung, misalnya terhadap organ pernafasan. Kerja insang akan terganggu karena banyaknya materi terlarut yang ikut masuk ke dalam organ ini ketika organisme tersebut bernafas.

Hasil analisis kualitas air masih masuk dalam $\mathrm{pH}$ yang normal, Nilai $\mathrm{pH}$ air sungai yang normal berkisar antara 6,0 - 8,0 (Kristanto, 2002). Organisme perairan mempunyai kemampuan berbeda dalam mentoleransi pH perairan. Kematian lebih sering diakibatkan karena $\mathrm{pH}$ rendah daripada $\mathrm{pH}$ yang tinggi (Wijayanti, 2007). BOD 0,12 - 1,25 ppm (termasuk dalam kategori tercemar rendah di bawah $10 \mathrm{ppm}$ ). COD menunjukan nilai berkisar antara 15,54 - 40,58. Sedangkan Nilai COD yang paling tinggi untuk kehidupan biota perairan adalah sekitar $10 \mathrm{ppm}$.

Sungai yang termasuk dalam kategori tidak layak untuk kehidupan biota perairan berdasarkan nilai COD. (COD>10 ppm) mencapai 100\% dari 6 lokasi yang disurvei (Salmin, 2005). Kandungan karbondioksida bebas (CO2) dalam suatu perairan maksimal 20 ppm, lebih dari itu akan membahayakan kehidupan organism perairan. Kadar CO2 yang dikehendaki oleh ikan tidak lebih dari 12 ppm dengan kandungan 02 terendah adalah 2 ppm. Kadar CO2 perairan yang disurvei berkisar antara 2,80 - 5,19 ppm (Asmawi, 1983). Rendahnya kandungan TDS air sungai yang disurvei 65-131 mg/L sedangkan nilai standar baku mutu yang ditetapkan untuk TDS adalah $2.000 \mathrm{mg} / \mathrm{L}$. Nilai TSS berkisar 7-87 mg/L, sedangkan TSS standar baku mutu yang ditetapkan $50 \mathrm{mg} / \mathrm{L}$. Dalam pengukuran TSS dari lokasi yang disurvei hanya 1 lokasi yang memiliki TSS lebih dari $50 \mathrm{mg} / \mathrm{L}$ yang berarti sebagian besar sungai yang disurvei masih dalam standar baku mutu. Sedangkan Mesangat Hilir memiliki TSS paling tinggi sangat dimungkinkan karena berbatasan langsung dengan sungai besar yaitu sungai Kelinjau sebagai jalur keluarnya air dari rawa Mesangat. Hal ini seperti diungkapkan oleh
Ditya et al. (2014) bahwa kandungan TSS yang tinggi dapat disebabkan oleh limpasan air yang terbawa dari daerah yang lebih tinggi.

D0 perairan berkisar antara 2,86-3,19 mg/L yang meliputi 3 lokasi yang memiliki kadar DO $<3 \mathrm{mg} / \mathrm{L}$ yaitu Rakit, Luah Pring, Klan Limbot sementara 3 lokasi lainnya yaitu Sekgoy, Mesangat Hilir dan Kelinjau relatif lebih baik. Kemungkinan kondisi demikian dipengaruhi oleh kekuatan arus sungai atau sirkulasi aliran air. Luah Pring dan Klan Limbot relatif berarus lambat karena tidak langsung dilewati oleh aliran sungai dan kondisi perairan banyak ditumbuhi vegetasi terapung, sedangkan lokasi rakit merupakan muara dari beberapa lokasi rawa yang terfragmentasi membentuk perairan terbuka.

Berbeda dengan Sekgoy, Mesangat Hilir dan Kelinjau yang merupakan aliran sungai yang berarus deras dan realtif bersih dari vegetasi terapung, terutama sungai Kelinjau sebagai sungai besar atau sungai utama di sepanjang Kecamatan Muara Ancalong. Kehidupan di air dapat bertahan jika ada oksigen terlarut minimum sebanyak $5 \mathrm{mg}$ oksigen setiap liter air (Sastrawijaya, 1991). Kadar DO $<3$ hanya layak digunakan untuk tujuan pengairan tanaman. Selain itu kemampuan air untuk membersihkan pencemaran juga ditentukan oleh banyaknya oksigen dalam air. Kadar DO biasanya berbanding terbalik dengan warna/kekeruhan air seperti pada kolam penampungan, akan tetapi lebih disebabkan oleh pergerakan/sirkulasi air.

Hal tersebut dikarenakan adanya gerakan air yang terus menerus di semua bagian perairan, mulai dari permukaan sampai dasar perairan sehingga Oksigen terlarut (DO) dalam ekosistem perairan mengalir cenderung relatif tinggi dan merata. (Salmin, 2005).

Menurut Mahida (1993) kelarutan oksigen didalam air bergantung pada keadaan suhu, pergolakkan di permukaan air, luasnya daerah permukaan air yang terbuka dan persentase oksigen di udara sekelilingnya. Oksigen terlarut dihasilkan melalui proses fotosintesis tumbuhan air dan dari udara masuk melalui proses difusi yang secara lambat menembus permukaan air. (Wardhana, 1995). Pada (DO) oksigen terlarut $4 \mathrm{mg} / \mathrm{l}$ hanya jenis organisme biota air atau ikan tertentu saja yang bisa bertahan hidup di perairan tersebut. Peningkatan suhu menyebabkan peningkatan kecepatan metabolisme dan respirasi organisme air, dan selanjutnya mengakibatkan peningkatan konsumsi oksigen (Nurhidayah et al., 2014). Peningkatan suhu juga menyebabkan terjadinya peningkatan dekomposisi bahan organik oleh mikroba (Effendy, 2003). Suhu di Rawa Mesangat relatif tinggi karena perairan terbuka sangat luas tanpa naungan vegetasi pohon sehingga sinar matahari langsung mengenai badan air. 
Tabel 1. Hasil Pengujian Kualitas Air di Rawa Mesangat

\begin{tabular}{|c|c|c|c|c|c|c|c|c|c|}
\hline \multirow{2}{*}{ Parameter } & \multicolumn{6}{|c|}{ Sampel } & \multirow{2}{*}{ Total } & \multirow{2}{*}{ Rerata } & \multirow{2}{*}{ Baku Mutu } \\
\hline & R1 & $\mathrm{R} 2$ & R3 & R4 & R5 & R6 & & & \\
\hline TSS(mg/l) & 87 & 19 & 7 & 30 & 23 & 27 & 193 & $32,16 \pm 28.03$ & 50 \\
\hline TDS (mg/l) & 96 & 71 & 65 & 77 & 76 & 131 & 516 & $86 \pm 24.38$ & 1000 \\
\hline Kekeruhan & 10 & 5 & 10 & 10 & 12 & 10 & 57 & $9.5 \pm 2.35$ & $(-)$ \\
\hline BOD-5 (mg/l) & 0.66 & 0.73 & 1.25 & 0.59 & 0.12 & 0.66 & 4.01 & $0,66 \pm 0.36$ & 3 \\
\hline $\mathrm{COD}(\mathrm{mg} / \mathrm{l})$ & 40.58 & 28.06 & 40.58 & 15.54 & 28.06 & 40.58 & 193.4 & $32,23 \pm 10.22$ & 25 \\
\hline $\mathrm{pH}$ & 7.31 & 6.75 & 6.67 & 6.5 & 6.78 & 7.41 & 41.42 & $6,90 \pm 0.37$ & $6-9$ \\
\hline DO & 3.19 & 3.06 & 2.97 & 2.99 & 2.86 & 3.19 & 18.26 & $3.04 \pm 0.13$ & 4 \\
\hline $\mathrm{Zn}$ & 0.003 & 0.003 & 0.02 & 0.003 & 0.003 & 0.003 & 0.035 & $0.01 \pm 0.01$ & 0.05 \\
\hline NH3-N & 0.19 & 0.04 & 0.01 & 0.12 & 0.04 & 0.21 & 0.61 & $0.10 \pm 0.08$ & $(-)$ \\
\hline $\mathrm{CO} 2$ & 3.2 & 2.8 & 5.19 & 4.39 & 4 & 4.79 & 24.37 & $4.06 \pm 0.92$ & $(-)$ \\
\hline$(\mathrm{CaCO})$ & 8.63 & 9.81 & 9.03 & 3.92 & 3.92 & 4.71 & 40.02 & $6.67 \pm 2.77$ & 50 \\
\hline
\end{tabular}

(R1=Mesangat Hilir; R2=Sekgoy Hulu; R3=Rakit; R4=Luah Pring; R5=Klan Limbot; R6=Kelinjau)

Sumber data diolah dari hasil uji Laboratorium Kualitas Air Fakultas Perikanan dan Ilmu Kelautan UNMUL

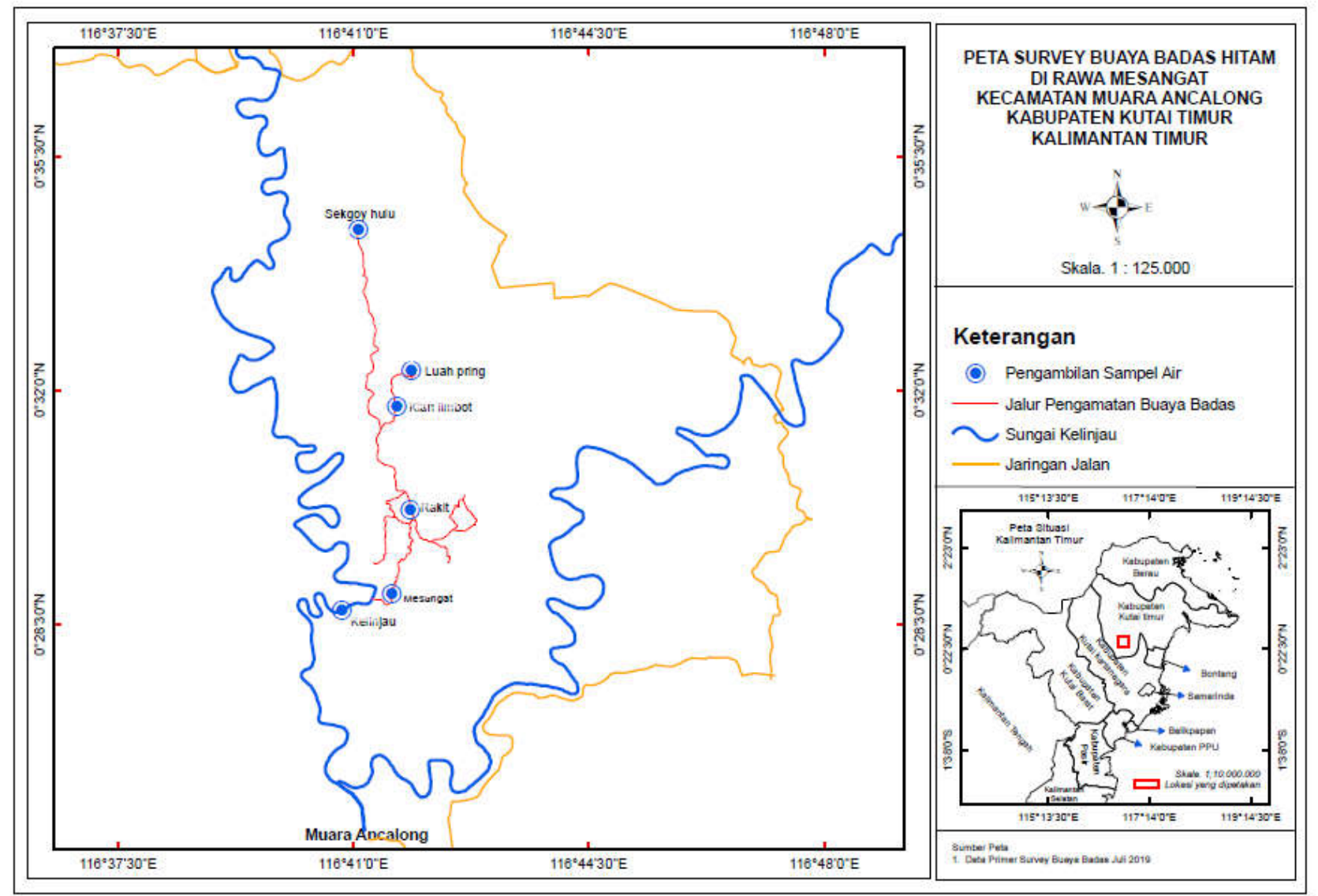

Gambar 2. Peta Lokasi Pengambilan Sampel Air di Lahan Basah Mesangat

\subsection{Tutupan Vegetasi Terapung}

Rawa merupakan bentuk peralihan antara air terbuka dan dataran. Rawa biasanya di kelilingi vegetasi, umumnya dangkal dan tanaman mengapung. Vegetasi rawa terdiri dari tumbuh-tumbuhan menahun yang selalu hijau yang di selingi oleh tanaman merambat. Kartamihardja et al. (2009) menyebutkan tipe hutan rawa memiliki 4 (empat) kondisi tutupan lahan, yaitu: habitat rawa banjiran di tepi sungai, rerumputan, tumbuhan semak belukar dan pepohonan.

Perairan Mesangat sendiri setidaknya terdapat 20 jenis vegetasi terapung yang selalu dinamis mengalami perubahan setiap tahun dan sangat tergantung pada rentang pergantian musim penghujan dan kemarau. Beberpa jenis tetap bertahan, beberapa lainnya hilang dan berganti. (Tabel 2)

Vegetasi air tumbuh pada zona litoral yaitu area dimana penetrasi cahaya cukup untuk mendukung pertumbuhan vegetasi (Krischik et al., 1997). Lebih dari 86 jenis tumbuhan air yang didominasi Salvinia, Eichornia crassipes, Mimosa pigra dan Polygonum barbatum (Gooner, 2000). Besarnya sedimen yang terbawa aliran air karena erosi akibat dari kegiatan pembukaan lahan dapat menyebabkan terjadi pendangkalan di kawasan lahan basah dan danau sebesar 4,0 mm/tahun (Budiono et al., 2007). Rawa Mesangat merupakan danau terisolasi dan tidak terpengaruh perairan sungai yang mengalir yang terhubung dengan Sungai Mahakam. 
Hasil penelitian Nurhidayah et al (2014) menyebutkan bahwa Salvinia molesta mampu menurunkan kandungan logam berat $\mathrm{Zn}$ sebesar $49 \%$, dan menurunkan kadar TSS sebesar 70\% akan tetapi kurang mampu bertahan pada $\mathrm{pH}$ rendah. Kiambang (Salvinia molesta) merupakan salah satu tanaman fitoremidiator logam berat $\mathrm{Cd}$ dan $\mathrm{Cr}$ yang terdapat pada limbah cair (Sudibyaningsih, 2005). Vegetasi terapung Salvinia molesta banyak terdapat di perairan rawa Mesangat (Muslim et al., 2018; Platt et al., 2018; Stuebing et al., 2015). Salah satu dari macrophyte yang paling umum digunakan untuk pakan ikan adalah Salvinia molesta (Haller, 2009; Lynch, 2009; Nelson, 2009; Costa et al., 2010; Velichkova and Sirakov, 2013).

Gangguan rawa Mesangat selama beberapa dekade dengan kebakaran selama musim El Nino pada tahun 1980-an (Chokkalingam et al. 2005) memfasilitasi datang jenis eksotik yang tumbuh subur di area tersebut. Perubahan ini juga dapat dipercepat oleh aktivitas manusia, misalnya dari sisa-sisa pupuk buatan pertanian dan timbunan sampah kota yang memperkaya danau dengan buangan sejumlah nitrogen dan fosfor. Akibatnya terjadi ledakan populasi ganggang atau blooming, sehingga terjadi produksi detritus yang berlebihan yang akhirnya menghabiskan suplai oksigen di danau tersebut. Pengkayaan danau seperti ini disebut eutrofikasi. Eutrofikasi menyebabkan air tidak dapat digunakan lagi dan mengurangi nilai keindahan danau.

Jenis yang paling menginvasi menyebar subur sebagai gulma Eichornia crassipes and Salvinia cucullata. Vegetasi yang tumbuh subur sebagai invasif gulma air menyebabkan jalan air buntu dan menyebabkan kedangkalan perairan sehingga akses terbatas yang dahulu terbuka selama periode 20092011 (Behler et al., 2018). Sedangkan Ipomea aquatica, meskipun bukan vegetasi dominan tetapi dapat bermanfaat bagi perairan Mesangat. Jenis ini dapat menurunkan kandungan COD, BOD pada limbah (Rane et al., 2016)

Tumbuhan muncul berakar di dasar danau dan menembus permukaan air. Tumbuhan ini membantu melindungi sempadan sungai, danau atau rawa dan membantu menstabilkan partikel dalam sedimen, mencegah turunnya kejernihan air (Krischik et al., 1997). Tumbuhan air memiliki kemampuan secara umum untuk menetralisir komponen-komponen tertentu di dalam perairan, dan hal tersebut sangat bermanfaat dalam proses pengolahan limbah cair (Stowel et al. 2000), akan tetapi harus dikelola dengan tepat sehingga dapat berfungsi sebagai saringan hidup secara optimal (Suriawiria, 2003).

Bioremediasi dengan dengan tumbuhan air dapat meningkatkan kualitas fisik, kimia dan mikrobiologis dari kondisi yang tidak memenuhi syarat menjadi memenuhi syarat sesuai baku mutu yang telah ditetapkan. (Yusuf, 2008)

Enceng gondok E. crassipes memiliki kecepatan tumbuh yang tinggi sehingga tumbuhan ini dianggap sebagai gulma yang dapat merusak lingkungan perairan. Enceng gondok dengan mudah menyebar melalui saluran air ke badan air lainnya (Sendi, 2014). Walaupun enceng gondok dianggap sebagai gulma di perairan, tetapi sebenarnya ia berperan dalam menangkap polutan logam berat. Enceng gondok mampu menyerap logam cadmium, merkuri, nikel, dan logam kromium (Upit et al., 2011).

Salvina molesta atau kiambang merupakan salah satu tanaman fitoremediator logam berat $\mathrm{Cd}$ dan $\mathrm{Cr}$ yang terdapat pada limbah cair, serta mampu beradaptasi pada lingkungan dengan kondisi salinitas rendah $(<10 \%)$ dan mampu tumbuh pada nutrisi yang rendah. Selain itu, secara morfologi $S$. molesta memiliki diameter daun yang relatif kecil (rata-rata 2$4 \mathrm{Cm}$ ), tetapi memiliki perakaran yang lebat dan panjang (Nurma et al., 2016). S. Molesta dapat secara efektif menyerap polutan, namun tidak menghalangi penetrasi cahaya kedalam perairan. Aktivitas tanaman ini mampu mengolah air limbah dengan efisien tinggi. Selain itu juga dapat menurunkan partikel tersuspensi secara biokimiawi (berlangsung lambat) dan mampu menyerap logam berat seperti $\mathrm{Cr}$, $\mathrm{Pb}, \mathrm{Hg}, \mathrm{Cd}, \mathrm{Cu}, \mathrm{Fe}, \mathrm{Mn}$ dan $\mathrm{Zn}$. Kemampuan menyerap logam berat persatuan berat kering lebih tinggi pada tanaman umur muda dibanding umur tua (Irhamni et al., 2017).

Menurut Widyastuti (2008), menyebutkan bahwa S. molesta tergolong dalam tumbuhan air yang muncul di atas permukaan, sehingga oksigen hasil fotosintesis dilepas ke udara. Soegiarto et al. (1978), menyatakan bahwa morfologi daun yang lebar dan tebal mengakibatkan penggunaan oksigen semakin besar.

E. crassipes, dan S. molesta memberikan suplai oksigen yang lebih kecil pada proses fotosintesa dibandingkan penyerapan oksigen pada proses respirasi karena sebagian oksigen yang dihasilkan akan dilepas ke udara dan hanya sebagian kecil yang dilepas ke air. Sementara itu, akar dari kedua tumbuhan tersebut berada di dalam air. Akar tidak berperan terhadap fotosintesis tetapi justru melakukan respirasi. Maka keberadaan akar kedua jenis tumbuhan air tersebut akan mengurangi jumlah oksigen terlarut dalam air. Hal itu juga dikarenakan bulu akarnya sangat lebat. (Puspitaningrum et al., 2012).

Suplai oksigen S. molesta paling rendah terjadi pada perairan, karena akar $S$. molesta tidak mengandung klorofil, sebab akarnya tidak berwarna hijau. Penurunan konsentrasi oksigen terlarut yang disebabkan oleh kehadiran E. crassipes relatif lebih sedikit dibanding dengan $S$. molesta. Hal ini disebabkan karena tangkai daun E. crassipes masih mempunyai klorofil, sehingga masih dapat mensuplai oksigen ke dalam air dan penurunan konsentrasi oksigen terlarut oleh pernafasan akar E. crassipes dapat dikurangi. Konsumsi oksigen oleh E. crassipes lebih sedikit daripada S. molesta. (Puspitaningrum et al., 2012). Salvinia molesta mampu menurunkan Seng (Zn) sebesar $49 \%$ dan TSS (Total Suspended Solid) 
sebesar 70\%. Tumbuhan air Perupuk mampu menurunkan Amoniak (NH3) sebesar 23\% (Nurhidayah et al., 2014)

Danau/rawa terbentung karena cekungan pada daratan yang terisi air dan setiap saat dapat terisi endapan sehingga menjadi tanah kering (Ewusie, 1990). Saat proses fotosintesis, tanaman air akan membentuk bahan organik dengan bantuan sinar matahari. Dari proses tersebut, tanaman ini akan menghasilkan oksigen yang dilepaskan ke dalam air. Dengan meningkatnya kadar oksigen di dalam air, ikan dan hewan lainnya dalam air dapat bernafas dengan baik (Odum et al. 2005), akan tetapi Fitoplankton yang tumbuh dengan pesat (blooming) dapat menjadikan perairan menjadi toksik (fitoplankton beracun, terutama dari kelompok Cyanophyceae) dan kondisi hypoxia (oksigen rendah) atau bahkan anoksik (tanpa oksigen) (Pratiwi et al., 2015). Vegetasi terapung hampir merata (>80\%) menutupi permukaan air di rawa Mesangat (Gambar 2)

Soerjani (1982) mendefinisikan tumbuhan air sebagai gulma air yang dalam keadaan dan waktu tertentu tidak dikehendaki, karena dianggap menimbulkan kerugian yang melebihi peranan yang menguntungkan. Tumbuhan air yang melimpah akan menimbulkan dampak kurang baik bagi perikanan, karena tumbuhan air yang melimpah akan mempercepat suatu pendangkalan perairan dan memperbesar evapotranspirasi. Penurunan hasil perikanan akibat rendah kadar oksigen terlarut di bawah permukaan air yang tertutup tumbuhan air, bila malam hari akan menurunkan kadar oksigen di perairan, serta tidak ada proses difusi antara air dengan udara (Marson, 2006).

Sumber oksigen terlarut dapat berasal dari difusi oksigen yang terdapat di atmosfer dan aktivitas fotosintesis oleh tumbuhan air, sebaliknya proses respirasi tumbuhan air dan hewan serta proses dekomposisi bahan organik dapat menyebabkan hilangnya oksigen dalam suatu perairan (Effendy, 2003). Peningkatan suhu juga akan mempercepat laju respirasi dan dengan demikian laju pengunaan oksigen juga meningkat (Afrianto et al., 1992). Perairan dangkal suplai oksigen didominasi oleh tanaman tepi (Boyd, 1990).

Rawa merupakan sebutan untuk semua daerah yang tergenang air, yang penggenangannya dapat bersifat musiman atau pun permanen dan ditumbuhi oleh tumbuhan (vegetasi). Genangan air dapat berasal dari hujan atau luapan air sungai pada saat pasang. Pada musim hujan lahan tergenang sampai satu meter, tetapi pada musim kemarau menjadi kering, bahkan sebagian muka air tanah turun mencapai jeluk (depth) $>50 \mathrm{~cm}$ dari permukaan tanah. (Noor, 2004).

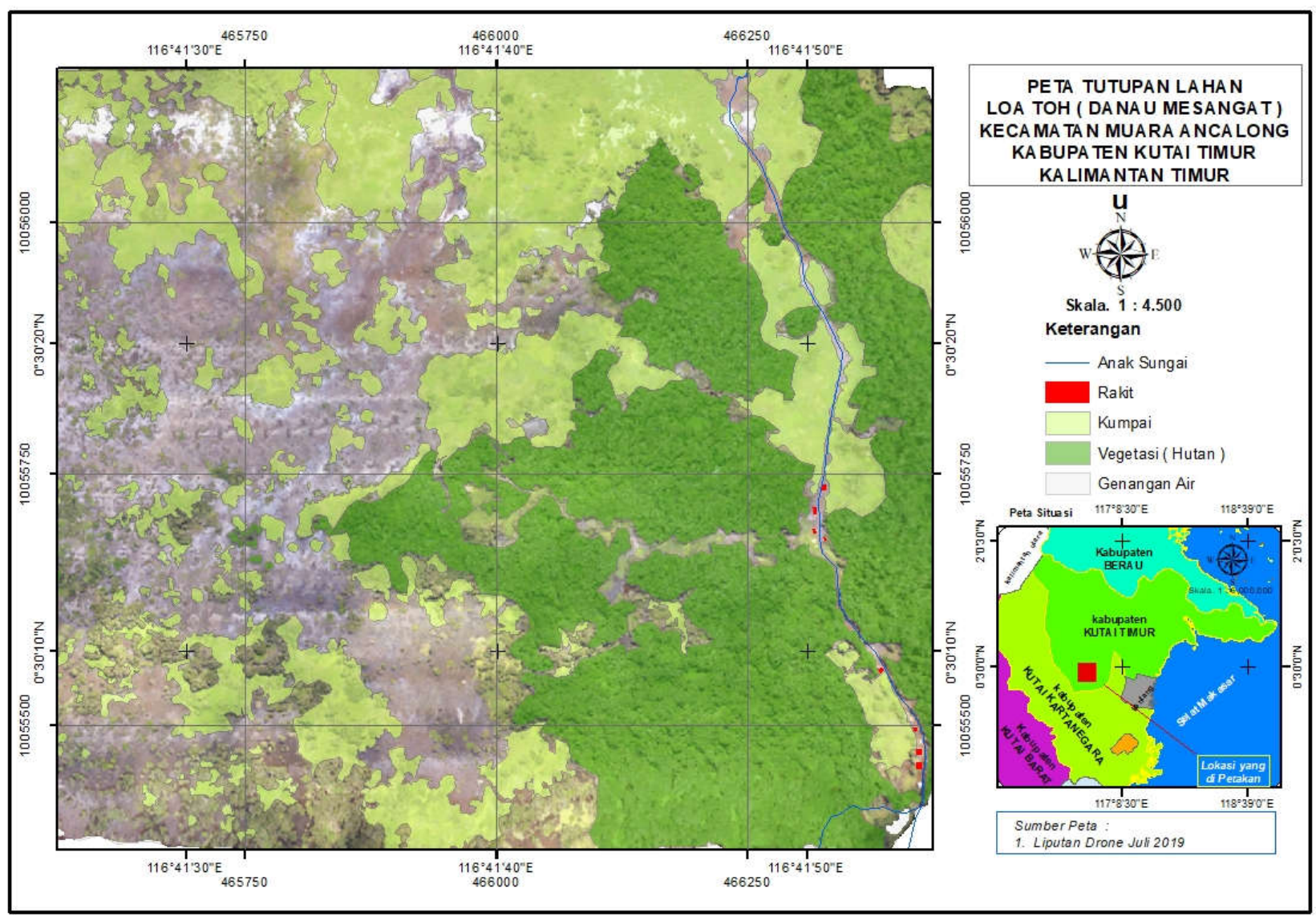

Gambar 3 Kondisi tutupan vegetasi terapung di periaran Mesangat 
Tabel 2. Jenis vegetasi terapung di rawa Mesangat: perbandingan dengan hasil penelitian sebelumnya. " $\sqrt{ }$ " = kehadiran; $" \sqrt{*}=$ Dominan

\begin{tabular}{|c|c|c|c|c|c|c|}
\hline \multirow[b]{2}{*}{ Vegetasi Terapung } & \multicolumn{6}{|c|}{ Hasil Penelitian } \\
\hline & $\begin{array}{c}\text { Kurniati } \\
(2008)\end{array}$ & $\begin{array}{c}\text { Staniewicz } \\
(2011)\end{array}$ & $\begin{array}{c}\text { Stuebing et } \\
\text { al (2015) }\end{array}$ & $\begin{array}{c}\text { Platt et al } \\
(2018)\end{array}$ & $\begin{array}{l}\text { Behler et } \\
\text { al (2018) }\end{array}$ & Hasil Terkini \\
\hline Leersia hexandra & $\sqrt{ }$ & & & & $\sqrt{ }$ & $\sqrt{*}$ \\
\hline Cyperus rotundus & & & & & $\sqrt{ }$ & $\sqrt{*}$ \\
\hline Diplazium sp & & & & & & $\sqrt{ }$ \\
\hline Ludwigia octovalvis & & & & & & $\sqrt{ }$ \\
\hline Panicum sp. & & & & & & $\sqrt{ }$ \\
\hline Eichhornia crassipes & $\sqrt{*}$ & $\sqrt{*}$ & $\sqrt{*}$ & $\sqrt{*}$ & $\sqrt{*}$ & $\sqrt{*}$ \\
\hline Scleria sumatrana & $\sqrt{ }$ & & & & $\sqrt{ }$ & $\sqrt{ }$ \\
\hline Salvinia molesta, & & & $\sqrt{*}$ & $\sqrt{*}$ & & $\sqrt{ }$ \\
\hline Nymphoides sp. & & & & & & $\sqrt{ }$ \\
\hline Polygonum barbatum & & & & & & $\sqrt{ }$ \\
\hline Hanguana malayana & $\sqrt{*}$ & & & $\sqrt{*}$ & $\sqrt{ }$ & $\sqrt{ }$ \\
\hline Polygonum sp. & & & & & & $\sqrt{ }$ \\
\hline Ipomea aquatic & & $\sqrt{*}$ & & & $\sqrt{ }$ & $\sqrt{ }$ \\
\hline Salvinia cucullata & & $\sqrt{*}$ & & & $\sqrt{*}$ & \\
\hline Hymenachne acutigluma & & & & & $\sqrt{ }$ & \\
\hline Imperata cylindrica & & & & & $\sqrt{ }$ & \\
\hline Miscanthus sp. & & & & & $\sqrt{ }$ & \\
\hline Salvinia terrestris & & & & & $\sqrt{ }$ & \\
\hline Nelumbo sp. & & & & $\sqrt{*}$ & & \\
\hline Thoracostachyum sumatranum & $\sqrt{ }$ & & & & & \\
\hline
\end{tabular}

\subsection{Ikan dan Organisme Perairan}

Berdasarkan hasil penelitian pada 6 titik pengamatan, kadar nitrat tertinggi adalah $0,21 \mathrm{mg} / \mathrm{L}$ sedangkan kadar nitrat terendah $0,01 \mathrm{mg} / \mathrm{L}$. Hasil tersebut bila dibandingkan dengan standar baku mutu air PP. No 82 Tahun 2001 (kelas II) untuk kegiatan budidaya ikan air tawar, masih sangat jauh dari batas yang ditentukan yaitu $10 \mathrm{mg} / \mathrm{L}$. Namun, hal ini tentunya harus mendapatkan perhatian karena kadar nitrat yang lebih dari $0.2 \mathrm{mg} / \mathrm{L}$ dapat menyebabkan terjadinya eutrofikasi perairan, dan selanjutnya dapat menyebabkan blooming sekaligus merupakan faktor pemicu bagi pesatnya pertumbuhan tumbuhan air seperti eceng gondok. Nitrat (NO3) adalah bentuk utama nitrogen di perairan alami dan merupakan sumber nutrisi utama bagi pertumbuhan fitoplankton dan tumbuhan air lainnya. Kadar nitrat yang lebih dari $5 \mathrm{mg} / \mathrm{L}$ menggambarkan telah terjadinya pencemaran (Tatangindatu et al., 2013). Laju pertumbuhan alga dan tumbuhan air dapat menurunkan kualitas perairan danau (Pratiwi et al., 2015).

Suhu udara berkisar $23-33,3^{\circ} \mathrm{C}$ dengan kelembaban udara antara 65 - 99\%. Pengukuran pada pagi, siang, sore dan malam hari (pukul $09.00-21.00$ WITA). Suhu atau temperatur merupakan faktor pembatas bagi pertumbuhan hewan bentos. Batas toleransi hewan bentos terhadap suhu tergantung pada jenis spesiesnya. Umumnya suhu di atas $30^{\circ} \mathrm{C}$ dapat menekan pertumbuhan populasi hewan bentos (Effendy, 2003). Makin tinggi temperatur pada suatu perairan, makin sedikit oksigen yang terlarut, sehingga lebih membahayakan kehidupan dalam perairan. Standar suhu normal untuk pertumbuhan ikan $25-32^{\circ} \mathrm{C}$ dan suhu $22-25^{\circ} \mathrm{C}$ adalah suhu normal perairan yang memungkinkan berlangsungnya kehidupan secara normal di dalamnya, baik kehidupan hewan maupun nabati (Sugiharto, 2003). Dari perolehan data lapangan, kisaran suhu pada ke- 6 lokasi antara $26-32^{\circ} \mathrm{C}$.
Dari hasil penelitian menunjukkan kisaran nilai Zn (seng) berkisar antara $<0,003-0,02 \mathrm{mg} / \mathrm{l}$. Nilai ini belum memenuhi persyaratan menurut PP No.82 tahun 2001 tentang pengelolaan kualitas air dan pengendalian pencemaran air. Karena nilai kandungan Zn menurut PP No.82 tahun 2001 tentang pengelolaan kualitas air dan pengendalian pencemaran air berkisar antara 0,05 - $2 \mathrm{mg} / \mathrm{l}$ sedangkan hasil penelitian nilai Zn masih tinggi.

Air banjir menyerang pemukiman penduduk dan menutupi sarang buaya, akibatnya kematian telur buaya. Karena aliran air dari sungai Mahakam tidak langsung masuk ke Danau Mesangat, sehingga proses sedimentasi lumpur tidak terjadi. (Kurniati, 2007b). Kondisi ini membuat kondisi habitat di Danau Mesangat tetap stabil. (Kurniati, 2008).

Rawa Mesangat dapat digolongkan sebagai perairan menggenang (lentik) yaitu suatu bentuk ekosistem perairan yang aliran atau arus airnya tidak memegang peranan penting. Hal ini karena aliran air tidak begitu besar atau tidak mempengaruhi kehidupan organisme yang ada di dalamnya. Pada perairan ini faktor yang amat penting diperhatikan adalah pembagian wilayah air secara vertikal yang memiliki perbedaan sifat untuk tiap lapisannya. Perairan menggenang di bagi dalam tiga lapisan utama yang didasari oleh ada tidaknya penetrasi cahaya matahari dan tumbuhan air, yaitu: Littoral, limnetik dan profundal, sedangkan atas dasar perbedaan temperatur perairannya, perairan menggenang dibagi menjadi 3 kelompok yaitu: metalimnion, epilimnion, dan hipolimnion. Kelompok organisme di perairan menggenang berdasarkan niche utama dalam kedudukan rantai makanan meliputi produser (autotrof), makro konsumer (heterotrof) dan mikrokonsumer (dekomposer). Kelompok organisme yang ada di perairan menggenang berdasarkan cara hidupnya meliputi: benthos, plankton, perifiton, nekton dan neuston. 
Danau oligotrofik dapat berkembang menjadi danau eutrofik akibat adanya materi-materi organik yang masuk dan endapan. Variasi atau keanekargaman hewan sangat kecil. Terdapat protozoa, rotifer, nematode, larva capung, Amphisoda, Isopoda, ikan, dan kura-kura. Pada lapisan dasar terdapat insekta, keong, dan ikan-ikan. (Masnaini, 2015)

Setidaknya terdapat lebih dari 37 jenis yang mungkin terdapat di rawa Mesangat termasuk 29 jenis ikan yang juga terdapat di danau Suwi (Nugroho et al., 2016). Ikan yang banyak dimanfaatkan oleh Nelayan hanya yang berukuran sedang - besar dan kurang dari 5 Jenis utama: Biawan, Gabus, Patin, Sepat Siam, Jelawat, Toman. Sedangkan jenis ikan lain yang berukuran kecil biasanya digunakan sebagai umpan untuk mamancing ikan yang berukuran lebih besar (Muslim and Garsetiasih, 2019)

Ikan Puyau (Nilem) banyak terdapat di rawa Mesangat (Yasiwa, 2016), sebagai jenis ikan pemakan tumbuhan (herbivore) yang habitatnya diperairan sungai dan rawa air tawar dengan kandungan oksigen yang cukup yaitu $5-8 \mathrm{mg} / \mathrm{l}$. Vegetasi air memiliki peran menyediakan nutrisi bagi hewan seperti ikan, larva serangga, siput dan invertebrate lainnya. Selain itu juga memberikan perlindungan bagi organism yang mendiami atau bergantung pada tubuh air (Wagner, 2004).

Pengendalian jenis dan jumlah tumbuhan akuatik merupakan salah satu cara untuk mengelola ekosistem perairan (Puspitaningrum et al., 2012). Jika tumbuhan air yang menutupi $10-20 \%$ dari luas perairan tergolong baik bagi perikanan (Boyd, 1990)

\section{Kesimpulan}

Perairan Mesangat secara umum relatif sehat bagi kehidupan biota perairan terutama Buaya Siam untuk saat ini. Ancaman yang mungkin terjadi jika kondisi perairan mengalami kekeringan berkepanjangan sehingga memicu pertumbuhan vegetasi terapung semakin meluas hingga menutupi sebagaian besar permukaan air.

Kualitas perairan Mesangat dan penutupan vegetasi terapung dapat saling mempengaruhi kualitas habitat bagi buaya Siam dan sumber makanan terutama jenis ikan. Kualitas lingkungan perairan yang baik tentu saja memberikan kualitas hidup yang lebih baik untuk semua organisme perairan secara langsung serta organism darat secara tak langsung.

Dampak dari meningkatnya populasi vegetasi terapung (eutrofikasi) secara langsung akan menurunkan populasi ikan sehingga dapat mengurangi daya dukung habitat bagi Buaya Siam. Selain itu, akibat yang dapat ditimbulkan adalah semakin sempitnya area berair yang dibutuhkan oleh Buaya Siam sehingga menurunkan daya tampung populasi Buaya Siam yang berada di perairan Mesangat.

\section{DAFTAR PUSTAKA}

Afrianto, F dan Liviawati, F. (1992). Pengendalian Hama dan Penyakit Ikan. Kanisius. Yogjakarta

Asmawi, S. (1983). Pemeliharaan Ikan dalam Karamba. PT Gramedia, Jakarta.

Behler N, L. Kopsieker, S. Agata, Suimah, R. Stuebing, T. Ziegler. (2018). Population size, demography and diet of the Siamese crocodile, Crocodylus siamensis (Schneider, 1801) in the Mesangat Swamp in Kalimantan, Indonesia, Raffles Bulletin Of Zoology. Vol. 66, Pp. 506-516

Boyd, C.E. (1990). Water Quality in Ponds for Aquaculture. Birminghan Publishing. Alabama.

Budiono, Danielle K, Syachraini dan R. Agustina. (2007). Keanekaragaman Hayati di danau dan lahan basah pada daerah Mahakam Tengah Kalimantan Timur, Indonesia. Laporan Teknis. 2005-2007.

Chokkalingam U, Kurniawan I \& Ruchiat Y. (2005). Fire, livelihoods, and environmental change in the Middle Mahakam peatlands, East Kalimantan. Ecology and Society, 10(1): 26.

Copper-Preston, H \& Jenkins, R. W. G. (1993).Natural history of Crocodylia.Fauna of Australia, 2A: 1-7.

Costa E, Mason V, Waller C. (2010). Indian Lake Plant Survey. An Interactive Qualifying Project Report. Worcester Polytechnic Institute, Worcester, MA.

Ditya, Y.C., Husnah, Gaffar, A.K., Muflikhah, N., Wibowo, A.,Kaban,S.,Marini, M., Wulandari, T.N.M.,Dwirastina, M.,Burnawi, Apriyadi, Junianto, R.S., Mersi, Rusmaniar, dan Nasution, D. (2014). Potensi dan Pemanfaatan Sumberdaya Perikanan di perairan Sungai Kumbe Kabupaten Merauke Provinsi Papua. Laporan Akhir Tahun Kegiatan Penelitian Balai Penelitian Perikanan Perairan Umum. Palembang. p.79

Effendy, H., (2003). Telaah Kualitas Air Bagi Pengelolaan Sumberdaya dan Lingkungan Perairan. 259 hal.

Ewusie J.Y. (1990). Introduction for Tropical Ecology. Penerbit ITB. Bandung

Gooner C. (2000). Birds of Lake Jempang and Middle Mahakam Wetlands, East Kalimantan. Kukila 11: 1336.

Haller W. (2009). Hydrilla. In: Gettys LA, Haller WT, Bellaud $\mathrm{M}$ (eds). Introduction to the Plant Monographs. Biology and Control of Aquatic Plants: A Best Management Practices Handbook. Aquatic Ecosystem Restoration Foundation, Marietta GA, USA.

Irhamni, P. Setiaty, E. Purba, dan Hasan W. (2017). Kajian Akumulator Beberapa Tumbuhan Air Dalam Menyerap Logam Berat Secara Fitoremediasi. Conference Paper • January 2017. Ha. 75-84. DOI: 10.5281/ZENODO.400012.

https://www.researchgate.net/publication/3172381 40. diakses tanggal $4 / 1 / 2018$

Kartamihardja, E. S., Purnomo, K., dan Umar, C. (2009). Sumberdaya ikan perairan umum daratan di Indonesia terabaikan. J.Kebijak.Perikan.Ind. 1(1): 1-15

Krischik VA, Newman R, Kyhl J. (1997). Managing Aquatic Plants in Minnesota Lakes. University of Minnesota. St Paul, MN, USA.

Kristanto, P. (2002). Ekologi Industri. Penerbit ANDI, Yogyakarta.

Kurniati, H. (2008). Danau Mesangat: Habitat Terakhir Buaya Badas Hitam, Crocodylus siamensis Di Indonesia. Fauna Indonesia. Vol 8 (2) Desember 2008: 25-28. 
Kurniati H. (2007a). Habitat Buaya air Tawar Potensial Di Luar Kawasan Lindungan Daerah Kalimantan. Fauna Indonesia. Vol 7 (2) Desember 2007: 26-32.

Kurniati, H. (2007b). Surveys Of Siamese Crocodile (Crocodylus Siamensis) Habitat In The Mahakam River, East Kalimantan: Zoo Indonesia 2007. 16(2): 5162

Lynch Jr WE. (2009). Controlling Filamentous Algae in Ponds. Agriculture and Natural Resources. Ohio State University, Columbus, OH, USA

Mahida, U.N. (1993). Pencemaran Air dan Pemanfaatan Limbah Industri. CV. Rajawali. Jakarta. 543 hal.

Marson. (2006). Jenis dan Peranan Tumbuhan Air bagi Perikanan di Perairan Lebak Lebung. BAWAL: Vol.1 No.2-Agustus 2006: 7-11

Masnaini, A. (2015). Makalah Ekosistem Air Tawar.

Muslim T, dan Garsetiasih. 2019. Potensi Sumber Makanan Alami Buaya Siam, Crocodylus siamensis (Schneider, 1801) Di Rawa Mesangat. Bunga Rampai Pengelolaan Lingkungan Kehati untuk Pemanfaatan Berkelanjutan. ISBN: 978-602-440-999-9. IPB press

Muslim T, dan R.B. Suba. (2018). A Preliminary Survey of Siamese Crocodile Habitat Preferences: Floating Vegetation on Lake Mesangat, Muara Ancalong, East Kutai, Indonesia. International Symposium on Tropical Forest and Environmental Science (ISTFES 2018). in press

Nelson L. (2009). Giant and common salvinia. In: Gettys LA, Haller WT, Bellaud M (eds). Introduction to the Plant Monographs. Biology and Control of Aquatic Plants: A Best Management Practices Handbook. Aquatic Ecosystem Restoration Foundation, Marietta GA, USA.

Noor A.A (2004). Permintakatan Daerah yang Rawan Pencemaran Air tanah Sebagai Dasar Perencanaan Penyediaan Air Bersih di Daerah Surakarta. Jurnal Forum Geografi. Volume 18. Surakarta: Fakultas Geografi, Universitas Muhammadiyah Surakarta.

Nugroho R.A, Galih Y, G. Santoso, Firman M. N, Hariani N, and Suimah S. (2016). A preliminary study on the biodiversity of fish in the Suhui River, Muara Ancalong, East Kutai, Indonesia. AACL Bioflux, Volume 9, Issue 2: 245 - 251

Nurhidayah, D. Sofarini, dan Yunandar. (2014). Fitoremediasi Tumbuhan Air Kiambang (Salvinia Molesta) Purun Tikus (Eleocharis Dulcis) dan Perupuk (Phragmites Karka) Sebagai Alternatif Pengolahan Limbah Cair Karet. EnviroScienteae 10 (2014) 18-26. ISSN 1978-8096.

Nurma. J.S, Tutik. N, Kristanti. I.P. (2016). Profil Protein Tanaman Kiambang (Salvinia Molesta) Yang Dikulturkan Pada Media Modifikasi Air Lumpur Sidoarjo. ITS Surabaya.

Odum, E.P., and G. W. Barrett., (2005). Fundamentals of ecology. 5th Edition. Thomson Learning, United State. $598 \mathrm{p}$.

Peraturan Daerah Provinsi Kalimantan Timur No. 02 Tahun 2011. Tentang standar baku mutu air

Peraturan Pemerintah No 82 tahun 2001 Tentang Pengelolaan Kualitas Air dan Pengendalian Pencemaran Perairan.

Platt, S.G., A Maslim, M. Lonnie, and L Matt. (2018). Securing The last Wild Siamese Crocodile Population in Indonesia: Preliminary results of surveys at lake Mesanget: 7-12. Crocodile Specialist Group Newsletter Volume 37 No 1 January 2018 - March 2018

Platt S.G, S. Heng, L. Kheng, B.L. Stuart, and J. Walston. (2006). Crocodylus Siamensis Along The Sre Ambel
River, Southern Cambodia: Habitat, Nesting, and Conservation. Herpetological Natural History, 9(2), 2006, pages 183-188

Pratiwi N. T.M. , S. Hariyadi, I. P. Ayu, A. Iswantari, M.Z. Novita dan Apriadi T. (2015). Kajian Aspek Ekologis dan Daya Dukung Perairan Situ Cilala. Jurnal Biologi Indonesia. 11 (2): 267 - 274 (2015)

Priadie, B. (2012). Teknik Bioremediasi sebagai alternatif dalam upaya pengendalian pencemaran air. Jurnal Ilmu Lingkungan, 10 (1), 38-48.

Puspitaningrum M, M. Izzati, Haryanti S. (2012). Produksi dan Konsumsi Oksigen Terlarut oleh Beberapa Tumbuhan Air. Buletin Anatomi dan Fisiologi Volume XX, Nomor 1, Maret 2012. Hal. 47-55.

Rane, N.R., Patil, S.M., Chandanshive, V.V., Kadam, S.K., Khandare, R.V., Jadhav, J.P., and Govindwar, S.P. (2016). Ipomoea hederifolia rooted soil bed and Ipomoea aquatica rhizofiltration coupled phytoreactors for efficient treatment of textile wastewater. Water Research, 96, 1-11.

Salmin, 2005. Oksigen terlarut (DO) dan kebutuhan oksigen biologi (BOD) sebagai salah satu indikator untuk menentukan kualitas perairan. Oseana, 30(3), 21-26.

Sastrawijaya, A. T. (1991). Pencemaran Lingkungan. Rhineka Cipta, Jakarta.

Sendi, B. (2014). Phytoremediation Waste Mercury Using Plant And System Reactor, Jurnal Ilmiah Sain Vol. 14 No.1.

Shahrul Anuar, M. S. and Stuebing, R. B. (1996). Diet, growth and movement of juvenile crocodiles Crocodylusporosus Schneider in the Klias River, Sabah, Malaysia. Journal of Tropical Ecology, 12: 651662.

Simpson B. K., Bezuijen M.R. Crocodiles. (2010). Status survey and conservation action plan. Third Edition: Siamese Crocodile Crocodylus siamensis.120-126. Crocodiles Specialist Group: Darwin.

Soegiarto, A. Sulistyo, W.A. Atmadja dan M. Mubarak (1978). Pertumbuhan Alga Laut Euchema spinosum pada Berbagai Kedalaman di Goba Pulau Pari. Oseanoligi di Indonesia.

Soerjani, M. (1982). Masalah gulma air di Indonesia. Prosiding Seminar Perikanan Perairan Umum. Indonesia. Hal: 33-41.

Stowel, R.R., J.C. Ludwig and G. Thobanoglous. (2000). Towad the Rational Design of Aquatic Treatments of Wastewater, Departement of Civil Engineering and Land, Air and Wastewater Resources, University of California, California.

Stuebing R, R. Sommerlad and A. Staniewicz. (2015). Conservation of the Sunda gharial Tomistoma schlegelii in Lake Mesangat, Indonesia. Int. Zoo Yb. (2015) 49: DOI:10.1111/izy.12068.

Sudibyaningsih (2005). Gulma Air Eichhorma crassipes dan Salvinia molesta sebagai Fitoremidiator Logam Kadmium dan Krom heksavalen dalam penanganan limbah cair. Agris. Record. Fakultas Biologi Universitas Jenderal Soedirman, Purwokerto (Indonesia).

Sugiharto. (2003). Dasar-Dasar Pengolahan Air Limbah, Universitas Indonesia, Jakarta

Suriawiria, U. (2003). Mikrobiologi Air dan Dasar-Dasar Pengolahan Buangan Secara Biologis, Penerbit Alumni, Bandung.

Staniewicz A .(2011). Diet and demography of Tomistoma schlegelii in Mesangat Lake, East Kalimantan, Indonesia. Mesangat Tomistoma report in June September 2011 
Tatangindatu. F, O. Kalesaran, Robert R. (2013). Studi Parameter Fisika Kimia Air pada Areal Budidaya Ikan di Danau Tondano, Desa Paleloan, Kabupaten Minahasa. Budidaya Perairan Mei 2013. Vol. 1 No. 2 : 819

Upit R.P, Asrul S.S, dan Nuning V.H. (2011). Kemampuan Tumbuhan Air Sebagai Agen Fitoremediator Logam Berat Kromium (Cr) yang Terdapat pada Limbah Cair Industri Batik, Berkala Perikanan Terubuk, ISSN 01264265 Vol. 39, No. 1 Februari 2011

Velichkova K.N., and Sirakov, I.N. (2013). The usage of aquatic floating macrophytes (Lemna and Wolffia) as biofilter in Recirculation Aquaculture System (RAS). Turkish J Fish Aquat Sci 13: 101-110.

Wagner K. (2004). The Practical Guide to Lake Management in Massachusetts. A Companion to the Final Generic Environmental Impact Report on Eutrophication and Aquatic Plant Management in Massachusetts.

Wardhana A.W.(1995). Dampak Pencemaran Lingkungan, Edisi II, hal. 35, Andi Offset, Yogyakarta.
Wibowo P. (1997). Hasil Temuan Survei Lahan Basah di Kalimantan: Seminar Pemaparan Hasil-Hasil Temuan Teknis Proyek UK-Indonesia di bidang Pengelolaan Hutan Tropis di Indonesia: Sub-Proyek Konservasi Suaka Margasatwa Danau Sentarum (1992 - 1997) Bogor, 16-17 Juni 1997. Wetlands InternationalIndonesia Programme. Bogor: 1-9

Widyastuti, Y.R. (2008). Peningkatan Produksi Air Tawar melalui Budidaya Ikan Sistem Akuaponik. Prosiding Seminar Nasional Limnologi IV, LIPI, Bogor : 62-73

Wijayanti H. (2007). Kualitas Perairan di Pantai Kota Bandar Lampung Berdasarkan Komunitas Hewan Makrobenthos. Tesis. Program Pascasarjana, Universitas Diponegoro. Semarang.

Yasiwa (2016). Kawasan Ekosistem Esensial Danau Mesangat dan Kenohan Suwi. Annual Report. 20 p

Yusuf, G. (2008). Bioremediasi Limbah Rumah Tangga Dengan Sistem Simulasi Tanaman Air. Jurnal Bumi Lestari. 8 (2): 136-144. 